\title{
The Determinants of Cervical Cancer Early Detection Behaviour with VIA Test Method in Visitors of Policlinic "KIA-KB" in Kassi-Kassi Public Health Centre of Kota Makassar
}

Ummul Qura*, Jumriani Ansar, Dian Sidik Arsyad, Indra Dwinata, Muh. Ikhsan, Suriah.

Faculty of Public Health, Hasanuddin University, Makassar, Indonesia

*Correspondence: ummulqurahasan@gmail.com; Telp.: +6281342953780

Received 07 August 2019; Accepted 09 September 2019; Published 09 September 2019

\begin{abstract}
Background: Cervical cancer can be recognized at the pre-cancer stage by doing early detection test in married women. One of the cervical cancer early detection methods is Visual Inspection with Acetic Acid (VIA) test. The coverage of the early detection of cervical cancer through VIA test method in 2017 was still very low, i. e. $1.03 \%$ from the national target of $50 \%$. The research aims to know the determinants of cervical cancer early detection behaviour by using IVA test method in visitors of Policlinic KIA-KB (Pediatric and Family Planning Polyclinic) in Kassi-Kassi Public Health Center.

Methods: The research was observational analytical research with cross sectional study design. The population of the study was all women of fertile couple that visited Policlinic KIA-KB in Kassi-Kassi Public Health Center and lived within the coverage area of Kassi-Kassi Public Health Center, which amounted to 135 women. The samples were 101 women that were collected by using accidental sampling technique.

Results: The results showed that there was a relation between knowledge $(p=0.000)$, attitude $(p=0.005)$, husband support $(p=0.000)$, as well as health worker support $(p=0.000)$ and early detection behaviour by using IVA test method.

Conclusions: Meanwhile, there was no relation between education and early detection behaviour by using IVA test method. There should be proactive and creative actions from health workers in improving the knowledge of the targets and their husbands about early detection of cervical cancer.
\end{abstract}

Keywords: determinant, early detection, IVA 


\section{Epidemiology and Society Health Review $\mid \mathbf{E S H R}$}

\section{INTRODUCTION}

Cervical cancer is the occurrence of abnormal cell growth at the cervix that turns into cancer (1). Based on the data obtained from World Health Organization (WHO) in 2016, the number of cervical cancer cases placed fourth after breast cancer, colorectal cancer, and endometrium cancer in women with a total number of 530,000 of new cases in 2012 , whereas $7.5 \%$ of them caused death aside from all the cancer impacts on women (2). Meanwhile, the incidence of cancer in Indonesia estimated by Globocan, International Agency for Research on Cancer (IARC) in 2012 was 134 per 100,000 citizens. Leading with the highest incidence in women was breast cancer with 40 per 100,000, followed by cervical cancer with 17 per 100,000 and colorectal cancer with 10 per 100,000 women (3).

From the data obtained from Riskesdas in 2013, the estimated number of cervical cancer patients in South Sulawesi Province placed $6^{\text {th }}$ as the area with the highest number of patients with 3,400 cases (4). According to the data obtained from the Health Office of South Sulawesi Province, there were 460 cases of cervical cancer in 2015, while in 2016 there were 319 cases (5). On the other hand, the number of cervical cancer cases in Kota Makassar was 117 in 2015 and 64 in 2016 (6).

The incidence of cervical cancer can be decreased by making primary efforts, such as conducting counselling activities more often for the citizens to lead a healthy life, avoiding risk factors of the cancer, having vaccination with Human Papillomavirus (HPV) vaccine and having early detection test (7). Having early detection is an effort made to clinically identify diseases before getting diagnosed by having certain examination or test and identifying the disease as early as possible, which is in the early stage of the disease. Thus, it is expected that the disease can be treated immediately. One of the screening and early detection methods for cervical cancer is Visual Inspection with Acetic Acid (VIA), which is an alternative screening choice in Indonesia because it is easy, practical, and can be carried out in every maternity check-up centre. Furthermore, the tools needed for the screening are quite simple (8).

The total number of women who had an early detection of cervical cancer with IVA test method in Indonesia in 2017 was 2.2 million (5\%) of the entire population with a total of 34 million women. Meanwhile, the specified target for screening on the national level is $50 \%$ for women aged $30-50$ within the period of 5 years or until the year of 2019 (9).

From the health profile data of South Sulawesi Province in 2017, the coverage of the early detection with IVA test method was only $2.6 \%$ (5). On the other hand, from the health profile data of Kota Makassar in 2017, the coverage of the early detection with IVA test method was 2803 women (1.03\%) from the total target of 450,395 . From the same source, we found that Rappocini Sub-district was the area that had the lowest level of IVA test coverage among 14 sub-districts in Kota Makassar with only $0.16 \%$ coverage. Kassi-Kassi Public Health Center was one of the health centers located in Rappocini Sub-district with the highest number of target fertile women from 46 health centers that were located in Kota Makassar, amounting to 14,499 people. Out of all 


\section{Epidemiology and Society Health Review $\mid \boldsymbol{E S H \boldsymbol { R }}$}

the target fertile women, only $104(0.72 \%)$ of them had IVA test with IVA positive amounting to 6 people (5.7\%) in 2017 (6).

From the data above, the researcher was interested in conducting a study on the Determinants of Cervical Cancer Early Detection Behaviour with VIA Test Method in Visitors of Policlinic KIA-KB (Pediatric and Family Planning Polyclinic) in Kassi-Kassi Public Health Center of Kota Makassar. The researcher was aware of the time and resource limitation. Thus, the researcher only focused on examining five factors (education, knowledge, attitude, husband support, and health worker support) that were considered to be related to the coverage accomplishment of cervical cancer early detection with IVA test method.

\section{METHODS}

\section{Study design}

The research method and design for the study was observational analytical with cross sectional design, which is a research design for examining correlation dynamics among risk factors or the effects caused with an approach, observation or data collection done at the same time or point time approach.

\section{Setting}

The study was conducted in Kassi-Kassi Public Health Center with the coverage area of Rappocini Sub-district of Kota Makassar from September $24^{\text {th }}$ to October $20^{\text {th }}$ of 2018.

\section{Data source and data collection}

The data collection techniques used for the study were interview and literature analysis. The primary data was obtained from the interview with the respondents through questionnaire. Meanwhile, the secondary data was obtained from the data of coverage area of early detection of cervical cancer with VIA test method from the health office of South Sulawesi and Kota Makassar. From the same source, the data on the number of women of fertile couple in Kassi-Kassi Health Centre was also obtained.

\section{Sample population}

The population of the research was all women of fertile couple who visited Policlinic KIA-KB in Kassi-Kassi Health Centre from August, with a total number of 135 people. With Accidental Sampling technique, a total of 101 respondents were selected.

\section{Variables}

The study was conducted to find out the relation between the independent variables (education, knowledge, attitude, husband support, and health worker support) and the dependent variable (cervical cancer early detection behaviour with VIA test method). 


\section{Epidemiology and Society Health Review $\mid \mathbf{E S H R}$}

\section{Analysis}

The data analysis techniques used were univariate and bivariate analyses with chisquare test.

\section{Ethical approval}

This research did not use ethical approval because on the field, the researchers only used informed consent which was the agreement to be a respondent in this research and no biological intervention was made to the respondent. In this study, the data collection was conducted by interviewing respondents based on each question prepared in the form of a research questionnaire.

\section{RESULTS}

\section{Result 1}

Table 1 The Distribution of Respondents Based on the Respondents' Characteristics in Visitors of Policlinic KIA-KB in Kassi-Kassi Health Center Kota Makassar

\section{Respondents' Characteristic Frequency Percentage (\%)}

(n)

\begin{tabular}{lcc}
\hline Age Group (year) & 5 & \\
$15-19$ & 13 & 5.0 \\
$20-24$ & 26 & 12.9 \\
$25-29$ & 25 & 25.7 \\
$30-34$ & 16 & 24.8 \\
$35-39$ & 13 & 15.8 \\
$40-44$ & 3 & 12.9 \\
$45-49$ & 3.0 \\
\hline Education & 1 & \\
Do Not Graduate Elementary School & 4 & 1.0 \\
Elementary School Graduate & 11 & 4.0 \\
Junior High School/Equivalence Graduate & 36 & 10.9 \\
Senior High School/Equivalence Graduate & 49 & 35.6 \\
University Graduate & 48.5 \\
\hline Occupation & & \\
Not Working (Housewife) & 61 & 60.4 \\
Civil Servant & 8 & 7.9 \\
Entrepreneur & 13 & 12.9 \\
Private Employee & 15 & 14.8 \\
Others (Honorarium Worker) & 4 & 4.0 \\
\hline
\end{tabular}

Source: Primary Data, 2018

Most respondents were in the age group of $25-29$ with 26 respondents $(25.7 \%)$. Based on their latest education, most respondents graduated from university with 49 respondents (48.5\%). Meanwhile, from the respondents' distribution based on their occupation, it was found that most respondents were not working/housewives with 61 respondents $(60.4 \%)$. 


\section{Epidemiology and Society Health Review $\mid \mathbf{E S H R}$}

\section{Result 2}

Table 2 Respondents Distribution Based on the Research Variables in Visitors of Policlinic KIA-KB in Kassi-Kassi Public Health Center Kota Makassar

\begin{tabular}{|c|c|c|}
\hline Observed Variable & $\begin{array}{l}\text { Frequency } \\
\text { (n) }\end{array}$ & $\begin{array}{c}\text { Percentage } \\
(\%)\end{array}$ \\
\hline \multicolumn{3}{|l|}{ Education } \\
\hline High & 85 & 84.2 \\
\hline Low & 16 & 15.8 \\
\hline \multicolumn{3}{|l|}{ Knowledge } \\
\hline High & 63 & 62.4 \\
\hline Low & 38 & 37.6 \\
\hline \multicolumn{3}{|l|}{ Attitude } \\
\hline Positive & 86 & 85.1 \\
\hline Negative & 15 & 14.9 \\
\hline \multicolumn{3}{|l|}{ Husband Support } \\
\hline Supportive & 59 & 58.4 \\
\hline Unsupportive & 42 & 41.6 \\
\hline \multicolumn{3}{|l|}{ Health Worker Support } \\
\hline Supportive & 52 & 51.5 \\
\hline Unsupportive & 49 & 48.5 \\
\hline $\begin{array}{l}\text { Early Detection Behaviour with VIA Test } \\
\text { Method } \\
\text { Yes } \\
\text { No }\end{array}$ & $\begin{array}{l}30 \\
71\end{array}$ & $\begin{array}{l}29.7 \\
70.3\end{array}$ \\
\hline
\end{tabular}

Source: Primary Data, 2018

From the education variable, it was found that 85 respondents $(84.2 \%)$ had a high education, while 16 respondents $(15.8 \%)$ had a low education background. From the knowledge variable, we found that 63 respondents $(62.4 \%)$ had a high level of knowledge, while the other $38(37.6 \%)$ had a low level of knowledge. Meanwhile, from the attitude variable, 86 respondents $(85.1 \%)$ had a positive attitude and the other 15 respondents $(14.9 \%)$ had a negative attitude. The variable of husband support showed that 59 respondents (58.9\%) got support from the husband, while the 42 respondents $(41.6 \%)$ were lacking support. From the data obtained for health worker support, it was found that 52 respondents $(51.5 \%)$ got support and 49 respondents $(48.5 \%)$ did not get enough support. On the other hand, for the variable of cervical cancer early detection behaviour with VIA test method, 30 respondents $(29.7 \%)$ had early detection examination with VIA test method and 71 respondents $(70.3 \%)$ did not have early detection examination with VIA test method. 


\section{Epidemiology and Society Health Review $\mid \boldsymbol{E S H \boldsymbol { R }}$}

\section{Result 3}

Table 3 The Relationship between Independent Variable and Dependent Variable

\begin{tabular}{|c|c|c|c|c|c|c|c|}
\hline \multirow{3}{*}{ Independent Variable } & \multicolumn{4}{|c|}{$\begin{array}{c}\text { Early Detection } \\
\text { Behaviour with VIA } \\
\text { Test Method }\end{array}$} & \multicolumn{2}{|c|}{ Total } & \multirow[t]{3}{*}{$\boldsymbol{P}$} \\
\hline & \multicolumn{2}{|c|}{ Yes } & \multicolumn{2}{|c|}{ No } & \multirow[b]{2}{*}{$\mathbf{n}$} & \multirow[b]{2}{*}{$\%$} & \\
\hline & $\mathbf{n}$ & $\%$ & $\mathbf{n}$ & $\%$ & & & \\
\hline \multicolumn{8}{|l|}{ Education } \\
\hline High & 26 & 30.6 & 59 & 69.4 & 85 & 100.0 & $0.772^{*}$ \\
\hline Low & 4 & 25.0 & 12 & 75.0 & 16 & 100.0 & \\
\hline \multicolumn{8}{|l|}{ Knowledge } \\
\hline High & 27 & 42.9 & 36 & 57.1 & 63 & 100.0 & 0.000 \\
\hline Low & 3 & 7.9 & 35 & 92.1 & 38 & 100.0 & \\
\hline \multicolumn{8}{|l|}{ Attitude } \\
\hline Positive & 30 & 34.9 & 56 & 65.1 & 86 & 100.0 & $0.005^{*}$ \\
\hline Negative & 0 & 0.0 & 15 & 100 & 15 & 100.0 & \\
\hline \multicolumn{8}{|l|}{ Husband Support } \\
\hline Supportive & 28 & 47.5 & 31 & 52.5 & 59 & 100.0 & 0.000 \\
\hline Unsupportive & 2 & 4.8 & 40 & 95.2 & 42 & 100.0 & \\
\hline \multicolumn{8}{|l|}{ Health Worker Support } \\
\hline Supportive & 30 & 57.7 & 22 & 42.3 & 52 & 100.0 & 0.000 \\
\hline Unsupportive & 0 & 0.0 & 49 & 100 & 49 & 100.0 & \\
\hline
\end{tabular}

Source: Primary Data, 2018

Based on the data of the relationship between education and cervical cancer early detection behaviour with VIA test method, out of the 85 respondents who had a high education, there were 26 respondents $(30.6 \%)$ who got early detection with VIA test method. On the other hand, out of all the 16 respondents who had a low education, 4 respondents (25\%) got early detection with VIA test method. From the Fisher Exact test analysis result, a $p$ value of 0.772 was obtained, meaning that there was not any relationship between education and early detection behaviour with VIA test method.

From the data on the relationship between knowledge and early detection behaviour with VIA test method, out of the 63 respondents who had a high level of knowledge, 27 respondents $(42.9 \%)$ got early detection with VIA test method. On the other hand, out of the 38 respondents who had a low level of knowledge, 3 respondents $(7.9 \%)$ got early detection or cervical cancer with VIA test method. From the analysis result of the chi-square test, $p=0.000$ was obtained. Therefore, it can be concluded that there was a relationship between knowledge and cervical cancer early detection behaviour with VIA test method.

From the data on the relationship between attitude and early detection behaviour with VIA test method, out of the 86 respondents who had a positive attitude, 30 respondents $(34.9 \%)$ got early detection behaviour with VIA test method. Meanwhile, from the total 15 respondents who had a negative attitude, no one got early detection of cervical cancer with VIA test method. From the result of Fisher Exact test analysis, 


\section{Epidemiology and Society Health Review $\mid \boldsymbol{E S H R}$}

$p=0.005$ was obtained. Thus, it can be concluded that there was a relationship between attitude and cervical cancer early detection behaviour with VIA test method.

Based on the data obtained on the relationship between husband support and early detection behaviour with VIA test method, out of the 59 respondents who got support from their husbands, 28 respondents (47.5\%) got early detection of cervical cancer with VIA test method. Meanwhile, out of the 42 respondents who did not get enough husband support, 2 respondents (4.8\%) got early detection of cervical cancer with VIA test method. From the result of the chi-square test analysis, $p=0.000$ was obtained. Therefore, it can be concluded that there was a relationship between husband support and early detection behaviour of cervical cancer with VIA test method.

From the data on the relationship between health worker support and cervical cancer early detection behaviour with VIA test method, out of all 52 respondents who got support from the health worker, 30 respondents $(57.7 \%)$ got early detection of cervical cancer with VIA test method. On the other hand, from all the respondents who did not get enough support from health worker, no one got early detection of cervical cancer with VIA test method. From the result of the chi-square test analysis, $p=0.000$ was obtained. Therefore, it can be concluded that there was a relationship between health worker support and early detection behaviour of cervical cancer with VIA test method.

\section{DISCUSSIONS}

Generally, the results of the research showed that cervical cancer early detection behaviour with VIA test method was still low. The test results on the five determinant variables of early detection behaviour of cervical cancer with VIA test method showed that four variables had a relationship with cervical cancer early detection behaviour with VIA test method, while the other one did not have any relationship with cervical cancer early detection behaviour with VIA test method in visitors of Policlinic KIA-KB in Kassi-Kassi Public Health Center, Rappocini Sub-district, Kota Makassar.

Education is one of the factors that influence someone, and one's attitude on healthy lifestyle, in motivating oneself to contribute to development and, generally, the higher the education the easier it is for someone to accept new information (10). Based on the result of the research, the majority of the respondents had high education $(84.2 \%)$, and most of respondents who had got early detection of cervical cancer with VIA test method were highly-educated women. The result of the Fisher Exact test analysis showed that there was no any relationship between education and cervical cancer early detection behaviour with VIA test method. One's preventive behaviour is not only influenced by the education he/she has, but is related to the information exposure he/she gets. Consequently, the respondents who had high education background with a lack of awareness in healthy behaviour were a result of the lack of knowledge on cervical cancer early detection behaviour with VIA test method. Therefore, their awareness and action in treating and preventing the disease were still lacking. The result of this study is in line with the study conducted by Nordiani and Wahyono, showing that there was no any relationship between education and VIA test visit (11). However, it was not in line with the findings made in 


\section{Epidemiology and Society Health Review $\mid \boldsymbol{E S H \boldsymbol { R }}$}

a study conducted by Lestari where there was a relationship between education and detection behaviour of cervical cancer (12).

Knowledge or cognitive is one domain that is very essential in shaping one's behaviour. One's knowledge on health may be an important factor preceding health behaviour. However, the expected health action may not be carried out, unless there is motivation to act upon the knowledge one possesses (13). Based on the result of the research, the number of respondents who had a high level of knowledge on cervical cancer and VIA test was greater (62.4\%). The analysis of chi-square test showed that there was a relationship between knowledge and cervical cancer early detection behaviour with VIA test method. The respondents who had a high level of knowledge also had good behaviour in conducting early detection of cervical cancer with VIA test method compared to the respondents who had a low level of knowledge. The respondents who had got early detection of cervical cancer with VIA test method found out about the information on cervical cancer and some preventive measures, as well as early detection of cervical cancer through electronic media. Additionally, women of fertile couple got VIA test when they had symptoms or participated in an annual event, such as a free VIA test conducted by the government. On the other hand, the majority of the respondents who had a low level of knowledge never got VIA test, influenced by the lack of information exposure they received, either because of the non-existent explanation made by health workers related to early detection of cervical cancer with VIA test method or because of the lack of awareness of the respondents to find any information on the importance of early detection of cervical cancer. This finding is in line with the study conducted by Siwi and Trisnawati, claiming that knowledge influenced behaviour in having VIA test (14). However, it is not in line with the finding in a study conducted by Sundari and Setiawati, stating that there was no any relationship between knowledge on early detection of cervical cancer with VIA test method and VIA test behaviour (15).

From the result of the statistical test, we found that there was a relationship between attitude and cervical cancer early detection behaviour with VIA test method. Attitude is the tendency to carry out an action. By knowing one's attitude, we can predict what response or action will be taken in response to a problem being faced. After one knows the stimulus or object, the next process is to observe and behave towards the stimulus or the health object (16). Respondents who got early detection of cervical cancer with VIA test method were those who had a positive attitude towards cervical cancer and early detection, compared to those who had a negative attitude, where there was no any respondent with negative attitude who got early detection of cervical cancer with VIA test method. However, in this study it was also found that the majority of the respondents who had a positive attitude never got early detection of cervical cancer with VIA test method. This was a result of the lack of understanding on VIA test, hence it led to the lack of cervical cancer early detection behaviour with VIA test method. This finding is in line with that of the study conducted by Sartiwi, indicating that there was a relationship between attitude and VIA test for early detection of cervical cancer (17). However, Dewi found a different finding where there was no any significant relationship between attitude and VIA test method (18).

Based on the research result on husband support, it can be concluded that there was a relationship between husband support and cervical cancer early detection 


\section{Epidemiology and Society Health Review $\mid \boldsymbol{E S H R}$}

behaviour with VIA test method. The respondents who did not get enough husband support had less enthusiasm to behave well because of the lack of influence from their closest companion, which was their husband who had a big role in motivating the respondents to improve their health. This result is in line with the finding of the study by Fauza, Aprianti and Azrimaidaliza where there was a significant relationship between husband support and VIA test participation (19). However, it is not in line with a study by Febriani which indicated that there was no any relationship between husband support and early detection of cervical cancer (7).

From the result of the study on health worker support, it can be concluded that there was a relationship between health worker support and cervical cancer early detection behaviour with VIA test method. Some factors that caused respondents not to get early detection with VIA test method regardless of the high support from health workers were the time unavailability to do the test and unpreparedness for the possibility to be positively diagnosed with VIA test. This finding is in line with that of the study conducted by Rasyid and Afni which indicated that there was a relationship between health worker support and fertile woman behaviour (20). A similar finding was also stated in a study by Sihombing and Windiyaningsih, showing that there was a significant relationship between health worker support and VIA test behaviour in fertile women (21).

\section{CONCLUSIONS}

The result of the study showed that the variables of knowledge, attitude, husband support, and health worker support had a relationship with cervical cancer early detection behaviour with VIA method in visitors of Policlinic KIA-KB in Kassi-Kassi Public Health Center of Rappocini Sub-district, Kota Makassar.

\section{AUTHORS' CONTRIBUTION}

The contributions from $\cup Q$ researchers in this study began from data collection, processing and data analysis. This research got a lot of inputs. The author of JA contributes addition information related to the background of the problem, DSA authors provide advice in terms of determining the variables that could have influenced a person's good behaviour, especially in women of fertile couple who want to do early detection of cervical cancer, one of them with the VIA examination method. From IDN who provided direction in determining the criteria for the study sample, MI authors provided input in determining the appropriate sampling technique in this study and the last contribution from the author $S$ in terms of addition in field discussion or discussion in this research.

\section{FUNDING}

Funding in this study was fully funded by the researcher.

\section{Acknowledgements}

The researcher would like to thank Universitas Ahmad Dahlan Yogyakarta for providing support and funding for this research. 


\section{Epidemiology and Society Health Review $\mid \boldsymbol{E S H \boldsymbol { R }}$}

\section{Conflict of interest}

There are no conflicts of interest

\section{REFERENCES}

1. Parapat FT, Setyawan H, Saraswati LD. Faktor Faktor Yang Berhubungan Dengan Perilaku Deteksi Dini Kanker Leher Rahim Metode Inspeksi Visual Asam Asetat Di Puskesmas Candiroto Kabupaten Temanggung. e-Journal. 2016;4(4):363-70.

2. WHO. Human papillomavirus (HPV) and cervical cancer [Internet]. 2016 [cited 2018 Feb 22] Available from: http://www.who.int/mediacentre/factsheets/fs380/en/

3. Globocan. Estimated Cancer Incidence, Mortality and Prevalence Worldwide in 2012 [Internet]. WHO. 2012 [cited 2018 Feb 22]. Available from: http://globocan.iarc.fr/Pages/fact_sheets_population.aspx

4. Kemenkes RI. Buletin Situasi Penyakit Kanker. Jakarta: Kementerian Kesehatan; 2015.

5. Dinkes Provinsi Sulawesi Selatan. Laporan Kasus Penyakit Kanker di Sulawesi Selatan Tahun 2017. Makassar; 2017.

6. Dinkes Kota Makassar. Data Cakupan Pemeriksaan IVA Di Kota Makassar Tahun 2017. Makassar; 2017.

7. Febriani CA. Faktor-Faktor Yang Berhubungan Dengan Deteksi Dini Kanker Leher Rahim Di Kecamatan Gisting Kabupaten Tanggamus Lampung. Jurnal Kesehatan. 2016;7(2):228-37.

8. Kustiyati S, Winarni. Deteksi Dini Kanker Leher Rahim Dengan Metode IVA Di Wilayah Kerja Puskesmas Ngoresan Surakarta. Jurnal GASTER. 2011;8(1):681-94.

9. Kemenkes RI. Seluruh Pegawai Kemenkes Dihimbau Lakukan Tes IVA dan SADANIS [Internet]. 2017 [cited 2018 Mar 15]. Available from: http://webcache.googleusercontent.com/search?q=cache:http://www.depkes.go.i d/article/view/17100300001/seluruh-pegawai-kemenkes-diimbau-lakukan-tesiva-dan-sadanis-.html

10. Taufia D. Faktor-Faktor Yang Berhubungan Dengan Perilaku Wanita Pasangan Usia Subur (PUS) Dalam Deteksi Dini Kanker Leher Rahim Metode IVA Di Wilayah Kerja Puskesmas Nanggalo Padang Tahun 2017 [Skripsi]. Padang: Politeknik Kesehatan Kemenkes; 2017.

11. Nordianti ME, Wahyono B. Determinan Kunjungan Inspeksi Visual Asam Asetat di Puskesmas Kota Semarang. Jurnal HIGEIA. 2018;2(1):33-44.

12. Lestari S. Hubungan Tingkat Pendidikan, Pengetahuan dan Sikap Ibu Rumah Tangga Dengan Perilaku Deteksi Dini Kanker Serviks Metode IVA di Puskesmas Jaten II Kabupaten Karanganyar [Skripsi]. Surakarta: Universitas Sebelas Maret; 2012. 


\section{Epidemiology and Society Health Review $\mid \boldsymbol{E S H \boldsymbol { R }}$}

13. Notoatmodjo S. Ilmu Perilaku Kesehatan. Edisi 2. Jakarta: Rineka Cipta; 2014.

14. Siwi RPY, Trisnawati Y. Faktor-Faktor yang Mempengaruhi Perilaku Pemeriksaan IVA (Inspeksi Visual Asam Asetat) Dalam Deteksi Dini Kanker Serviks Pada Pasangan Usia Subur. Jurnal Global Health Science. 2017;2(3):220-5.

15. Sundari, Setiawati E. Pengetahuan dan Dukungan Sosial Mempengaruhi Perilaku Deteksi Dini Kanker Serviks Metode IVA. Indonesian Journal Of Midwivery. 2018;1(1):6-11.

16. Notoatmodjo S. Pendidikan Dan Perilaku Kesehatan. Jakarta: Rineka Cipta; 2003.

17. Sartiwi W. Faktor-Faktor yang Berhubungan dengan Pemeriksaan Inspeksi Visual Asam Asetat (IVA) Terhadap Deteksi Kanker Servik Pada WUS di Wilayah Kerja Puskesmas Paninggahan Kabupaten Solok. Jurnal Medika Saintika. 2017;8(2):33-44.

18. Dewi L. Faktor-Faktor Yang Berhubungan Dengan Perilaku Wanita Usia Subur Dalam Deteksi Dini Kanker Serviks Dengan Metode Pemeriksaan Inspeksi Visual Asam Asetat (IVA) Di Wilayah Kerja Puskesmas Tanjung Hulu Pontianak Timur Tahun 2014. Jurnal PRONERS. 2014;1(1):1-10.

19. Fauza M, Aprianti, Azrimaidaliza. Faktor yang Berhubungan dengan Deteksi Dini Kanker Serviks Metode IVA di Puskesmas Kota Padang. Jurnal Promosi Kesehatan Indonesia. 2018;14(1):68-80.

20. Rasyid N, Afni N. Faktor-Faktor yang Berhubungan Dengan Perilaku WUS (Wanita Usia Subur) Tentang Deteksi Dini Kanker Leher Rahim Metode IVA (Inspeksi Visual Asam Asetat) Di Puskesmas Singgani. Jurnal Promotif. 2017;7(1):63-75.

21. Sihombing M, Windiyaningsih C. Faktor Penentu Pemeriksaan IVA Pada Wanita Usia Subur di Puskesmas Pademangan, Suku Dinas Kesehatan Jakarta Utara 2015. Jurnal Bidang Ilmu Kesehatan. 2016;7(1):421-6. 
Epidemiology and Society Health Review $\mid \boldsymbol{E S H R}$ 